\title{
26 The relative performance of federal and non-federal countries during the pandemic
}

\author{
David Cameron
}

\subsection{Introduction}

The story of COVID-19 can be divided into two broad, overlapping phases. The first phase covers the period from the initial outbreak of the pandemic at the beginning of 2020 until about January 2021. That is the time when - without a preventive vaccine - the world struggled to contain its spread and to provide health care to those who fell ill. The second phase of the story starts in early 2021, when effective vaccines began to be manufactured and administered to national populations. Assessing the performance of a country in the first phase focuses on how well the infection was contained and how many people lost their lives to the disease. Assessing performance in the second phase will continue to involve assessing infection-containment and deathreduction measures, but will in addition entail an evaluation of how effectively vaccinations were administered to a country's population. ${ }^{1}$ This chapter restricts itself to examining performance in the first phase.

How well have federations performed in comparison with non-federal countries? Is there any evidence to suggest that federations have handled the coronavirus crisis better or worse, or differently from unitary states? It is this matter that I propose to discuss in this chapter.

A pandemic is an acid test of the relationship between citizens and their governments, particularly in democracies. It can be compared to the total mobilization of civil society that was mounted in the United Kingdom, the United States, Canada and elsewhere during the Second World War, when governments made it clear that victory could only be achieved if every citizen played an active role in the war effort. In the COVID-19 pandemic, it was manifestly true that citizens who did not wear masks, maintain social distance, and avoid travel were putting themselves and society in mortal danger. Rarely has the link between individual behavior and collective well-being been more directly drawn. Governments at all levels attempted to strike the right balance between education, exhortation, peer pressure, and coercion for optimal response to the crisis.

In this chapter, we will be scrutinizing how the pandemic was managed, not how the economy was supported or how the balance was struck between the two. Balancing the conflicting pressures of public health and the economy is an inescapable part of the responsibility of all governments coping with the pandemic, but that is not as such the focus of this chapter. How effective have the public health and medical responses to the virus been? That is the question. Clearly, the economic pressures may have led governments to close down too late or open up too soon. If those policy 
choices have affected the performance of governments and populations in managing the pandemic, that will be reflected in the health outcomes, but the economy as such does not fall within the purview of this chapter.

\subsection{COVID-19 in OECD countries}

For purposes of economy of effort, and to achieve at least to some degree an applesto-apples comparison, the chapter will concentrate on Organisation for Economic Co-operation and Development (OECD) member countries. Member states are understood to adhere to two fundamental principles: they are expected to be democratic societies committed to the rule of law and the protection of human rights; and they are meant to have open, transparent, free-market economies. In some cases - such as Turkey, which is an OECD member listed as 'not free' in the 2020 Freedom House index - these commitments appear today to be more aspirational than actual, but nevertheless OECD countries do collectively constitute a grouping of states generally exhibiting these characteristics. ${ }^{2}$ In addition, OECD members are typically wealthier countries with more fully articulated economies and societies. ${ }^{3}$ Restricting our detailed analysis to this group reduces somewhat the range of variables one would otherwise have to consider and makes for a more manageable analytical exercise.

Nine of the 35 OECD members we are considering here ${ }^{4}$ are federations: Australia, Austria, Belgium, Canada, Germany, Mexico, Spain, Switzerland, and the United States of America. This offers a good range of federations of different types - with parliamentary and congressional systems, monarchical and republican forms, large and relatively small populations, and national and multinational social composition.

To assess the pandemic performance of the countries we are studying, we will use two rough and ready indicators.

- Number of COVID-19 cases per million population

- Number of COVID-19 deaths per million population

These two ratios offer at best a very rough guide to relative performance. The first, in particular, needs to be treated with great caution, given that an accurate assessment of the number of cases occurring in a country depends to a substantial degree on testing, as well as the nature of the system of testing and the extent of its use. Moreover, record-keeping and reporting capacity vary widely from one country to another (Hasell, Mathieu and Beltekian 2020). While there may be some data complexities associated with reporting on COVID-19 deaths per million, we assume those data are generally more reliable and comparable, and we will give priority to this indicator, using it to provide a rough ranking of country-by-country performance.

Table 26.1 reports the pandemic performance of OECD countries as of January 2021 against these two indicators. The primary ranking in the right-hand column indicates their rates of COVID-19 deaths per million of population. In the middle column, reporting on the number of cases per million of population, we indicate in brackets the relative ranking of the countries according to that indicator. OECD countries that are federal are noted by capital letters.

The first thing to note is that the nine federations (of the 35 OECD countries listed here) are arrayed up and down the scale from the top to the bottom. Australia is one 
Table 26.1 COVID-19 Case and Death Rates in OECD Countries as of January 2021

\begin{tabular}{|c|c|c|}
\hline $\begin{array}{l}\text { Countries (Federal Countries } \\
\text { in Capital Letters) }\end{array}$ & $\begin{array}{l}\text { Cases per Million (Rank } \\
\text { Order Indicated in } \\
\text { Bracketed Number) }\end{array}$ & $\begin{array}{l}\text { Deaths per Million } \\
\text { (Rank Order Indicated in } \\
\text { Bracketed Number) }\end{array}$ \\
\hline New Zealand & $474(1)$ & $5(1)$ \\
\hline South Korea & $1,473(3)$ & $26(2)$ \\
\hline AUSTRALIA & $1,129(2)$ & $36(3)$ \\
\hline Japan & 2,899 (4) & $39(4)$ \\
\hline Norway & $11,267(6)$ & $102(5)$ \\
\hline Finland & $7,685(5)$ & $114(6)$ \\
\hline Estonia & $30,693(12)$ & $267(7)$ \\
\hline Turkey & $28,808(11)$ & $295(8)$ \\
\hline Denmark & $33,609(14)$ & $328(9)$ \\
\hline Israel & $69,020(31)$ & $469(10)$ \\
\hline CANADA & $19,926(9)$ & $492(11)$ \\
\hline Greece & $14,581(8)$ & $520(12)$ \\
\hline Latvia & $32,344(13)$ & $553(13)$ \\
\hline Ireland & $37,983(17)$ & $570(14)$ \\
\hline GERMANY & $25,635(10)$ & $612(15)$ \\
\hline Slovakia & $43,313(21)$ & $697(16)$ \\
\hline Netherlands & $55,380(26)$ & $764(17)$ \\
\hline AUSTRIA & $44,936(22)$ & $821(18)$ \\
\hline Poland & $38,985(18)$ & $910(19)$ \\
\hline Lithuania & $64,881(30)$ & $916(20)$ \\
\hline Chile & $36,572(15)$ & $934(21)$ \\
\hline Portugal & $62,392(29)$ & $943(22)$ \\
\hline Colombia & 39,610 (19) & $997(23)$ \\
\hline SWITZERLAND & $58,845(27)$ & $1046(24)$ \\
\hline France & $46,640(23)$ & $1060(25)$ \\
\hline Sweden & $54,179(25 \mathrm{~A})$ & $1062(26)$ \\
\hline MEXICO & $13,675(7)$ & $1132(27)$ \\
\hline SPAIN & $54,179(25 \mathrm{~B})$ & $1169(28)$ \\
\hline Hungary & $37,222(16)$ & $1199(29)$ \\
\hline UNITED STATES & $76,243(33)$ & $1244(30)$ \\
\hline Italy & $40,800(20)$ & $1396(31)$ \\
\hline Czech Republic & $87,554(34)$ & $1403(32)$ \\
\hline United Kingdom & $53,729(24)$ & $1412(33)$ \\
\hline Slovenia & $75,919(32)$ & $1573(34)$ \\
\hline BELGIUM & $59,582(28)$ & $1796(35)$ \\
\hline
\end{tabular}

Source for case rates as of 24 January 2021: KFF COVID-19 Coronavirus Data Table by Country. Available from: https://www.kff.org/coronavirus-covid-19/fact-sheet/coronavirus-tracker/?utm source=web\&utm_medium=trending\&utm_campaign=covid-19; KFF's data sources are: Johns Hopkins University's Coronavirus Resource Center's COVID-19 map; WHO's Coronavirus Disease (COVID-19) situation reports. As we pointed out in footnote 4, we have excluded OECD countries with less than a million population (Iceland and Luxembourg). Source for death rates as of January 22, 2021: Statista; Statista's sources: Johns Hopkins University (CSSE); World Bank; Insee. The numbers are rounded. Available from: https://www.statista.com/statistics/1104709/coronavirus-deaths-worldwide-per-millioninhabitants/ [Accessed 6 April 2021].

of the OECD's best performers, coming in third in deaths per million and second in cases per million. On the other hand, the federation of Belgium is at the bottom in 35 th and final place for deaths per million, with the United States not far behind in position 30. The other six OECD federations are scattered between with no clear pattern, except perhaps for a very slight skewing toward the lower end of the ranking. 
As for the performance of non-federal OECD countries, there is a similar spread. Four of the top five performers are non-federal (New Zealand, South Korea, Japan, and Norway). Equally, four of the five poorest performers are non-federal (Slovenia, United Kingdom, Czech Republic, and Italy). ${ }^{5}$ Given that 26 of the 35 countries on the list are non-federal, it is perhaps not surprising to find them well represented at both the top and bottom of the ranking as well as in between.

\subsection{The best and the worst}

We will now examine in more detail those countries which find themselves either at the top of the list or the bottom.

We will begin by examining some of the poorest performers at the bottom of our list in Table 26.1. As we have noted, the country with the highest rate of deaths per million is a federation, the Kingdom of Belgium. It exemplifies to a high degree the link between governance and pandemic performance, although one would have to acknowledge as well that it is not aided by geography. Belgium is embedded in Europe, sharing a border with the Netherlands, Germany, Luxembourg, and France; its largest city, Brussels, is the de facto capital of the European Union, making it a destination for people from all over the continent.

With a society starkly divided between the French-speaking Walloons and the Dutch-speaking Flemish (plus a small German-speaking minority), the country began as a unitary state, but has been federalizing through a series of constitutional reforms that began in 1970. These alterations in the constitutional makeup of the country have not expressed a coherent design, but have been a series of decentralizing ad hoc arrangements reflecting the political and partisan pressures of the day (Bursens, Popelier and Meier 2021). The result has been a unique and highly complex federation composed of two imperfectly overlapping sets of units: three linguistically defined communities (Dutch, French, and German-speaking); and three territorially defined regions (Flanders, Wallonia, and the Brussels region). There are two distinct party systems, one for each major language community. When the pandemic struck, Belgium had been living under a caretaker government for a year, which was then hastily upgraded to full governing status in response to the crisis.

Theoretically, one might have expected that a small (11.5 million population), prosperous country with a highly developed health and social service sector would perform well in combating the coronavirus. However, Belgium did not do well, and the chief reason why seems to be lie primarily in its governance model. ${ }^{6}$ The recurrent difficulty the country has had in forming an effective federal government suggests an institutional deficiency, and the confused scattering of jurisdictional responsibilities has made decisive action difficult. For this system to work well, an unusually high degree of coordination and a considerable capacity for intergovernmental collaboration would be necessary, and these have been notably lacking during the crisis. In addition, competition between parties representing different communities undermined the potential for coherent action and blunted or confused the pandemic policy response. Beneath the Belgian governance model lies a deeply divided society, which has driven the transformation of the country from a unitary to a federal regime. That being said, there are other federal states with deep ethnocultural differentiation that have fared better. Canada, in 11th place in deaths per million, and Switzerland in 24th position provide examples of that. Belgium's institutional structure, then - itself the expression of a deeply divided society - appears to lie at the heart of its difficulties. 


\section{David Cameron}

The United States of America is sixth from the bottom in the OECD rankings and put in the second poorest showing among federal countries. As a rich and powerful country with a federal system offering a significant leadership and coordination role to the federal government, one might have expected the United States to be one of the highest performing federations on the list. It scored first in the Global Health Security Index in its capacity to respond to pandemics. That it did not perform as expected is chiefly the result of an abysmal failure of leadership at the national level and a partisan divide that is as evident throughout the American public-health system as it is elsewhere in US governance and society.

Former President Trump questioned and actively cast doubt on the seriousness of COVID-19 and the need to take public-health measures to combat it; as a result, the states were left to their own devices to a much greater extent than would otherwise have been the case. ${ }^{7}$ Trump downplayed the coronavirus, contradicted his senior public-health officials, encouraged the early re-opening of the economy, and asserted that the states have the primary responsibility to combat COVID-19 and to secure the personal protective equipment (PPE) they need. His abdication of national leadership fostered a confused national response to the crisis, which encouraged a patchwork of state policies and approaches, and contributed substantially to the poor performance of the United States in combating the disease (Camacho and Glickman 2020).

It might be said that Trump inadvertently activated American federalism by his conduct. After all, while US analysts and commentators tend to pay little attention to federalism in comparison with their counterparts in other federal countries, the US states in reality had and have an indispensable constitutional role to play in confronting a public-health crisis. State governors were responsible for many of the things that really mattered in the pandemic - like whether shops would remain open, masks had to be worn, or beaches were off limits. As the virus raged across the country, it revealed just how crucial the sub-national units in the US federation are in shaping a coherent and effective pandemic response. But it brought home another point as well: that the absence of leadership from Washington undermined not only the fashioning of an effective federal response to the virus, but the effectiveness of state-level action as well. The President is the national tone-setter; his denials licensed many citizens and some political leaders across the country to contest the science and reject the public-health advice. And Washington's abdication of its national coordination role fostered at times mutually destructive behavior among the states, manifest for example, in the desperate competition for public-health supplies. The lesson from this experience is that federalism does matter in a public-health crisis, but that the states cannot do their job effectively if Washington does not play its part.

The often-toxic partisan division amplified the incoherence of the nation's response. There was conflict and disagreement about the size of aid packages, support for state and local governments, locking down and opening up, and mask wearing. Federal-state and state-local quarrels often reflected the partisan composition of the senior government actors (Kincaid and Leckrone 2021). These conflicts offered opportunities for skeptical Americans to contest the seriousness of the virus and for some to turn the refusal to wear masks into a partisan badge of liberty. The fragmented, partly public, partly private US health care system added to the mix. At the time of writing - March 2021 - the United States leads the world in the total number of cases and deaths from the coronavirus (Johns Hopkins University Coronavirus Resource Center 2021). On the evidence, this overall approach has proven to be a highly ineffective way of managing the pandemic. 
What of poorly performing unitary countries? At or near the bottom of our list are Slovenia, the United Kingdom, the Czech Republic, and Italy. Given their size and significant position in Europe, we will focus our attention in this chapter on the United Kingdom and Italy. The Czech Republic will also be discussed very briefly.

Italy was the first country in Europe to face a major outbreak of the coronavirus. Thus, other countries in the region had the opportunity to learn from Italy's early COVID-19 experience. Thirty-fifth in the Global Health Index of pandemic preparedness, Italy did not start from a strong institutional position. Outbreaks in Italy were concentrated regionally (in the Lombardy, Emilia-Romagna, and Veneto regions in northern Italy), which placed acute strain on the local health institutions. Italy's population is the most elderly in Europe and, in contrast to the impact of the pandemic in some other European countries such as Germany, older Italians were the demographic most severely affected in the early phases. Italians have a relatively high rate of co-morbidities, and the median age of people dying from COVID-19 in Italy was 80 years. While Italy has a high functioning health care system, it is under-endowed with ICU beds, as compared to other countries; when people with mild symptoms were admitted to the hospitals in the early going, capacity was strained, making it a challenge to accommodate the really ill. Over-crowded hospitals then became incubators of infection leading to high infection rates for medical personnel. ${ }^{8}$

Italy's response to the crisis involved: the imposition of a quarantine to control the spread of the pandemic; the expansion of over-stretched medical facilities; and, as elsewhere, financial measures to support the failing economy (Nicola 2020). The relatively decentralized, 'federal country without federalism' system did not prove itself to be an effective instrument for addressing the pandemic (Palermo 2021). Italy's regions have grown more powerful in the 50 years since they were put in place, and - despite having primary responsibility for health care - the onset of the first wave of the pandemic led to a centralization of Italy's response.

The national government declared a state of emergency at the end of January 2020, setting the stage for implementing a set of regulations that applied throughout the country, whatever variation in concrete circumstances there may have been. National collaboration with regional governments was relatively limited. Contrary to the response in several explicitly federal systems, Francesco Palermo (2021) notes that the main instrument for managing intergovernmental relations in Italy, the Standing Conference Between the States and the Regions, actually met less frequently during this period than in normal times. As Palermo (2021) writes:

After a first phase of extreme centralization, the regions (and to some extent the municipalities) gradually resumed their functions. The asymmetric impact of the virus and the equally asymmetric response by the territories revealed both the potential of such an asymmetric territorial governance and the weaknesses of an incomplete, quasi-federal system, especially as far as unclear division of powers and insufficient intergovernmental relations (IGR) are concerned.

When infections began dropping in spring, the regional governments began to assert themselves, which led to more differentiation and greater collaboration. However, confusion about roles did not abate, partly because a more limited national emergency regime continued, and tensions, sometimes political, between state and region re-surfaced. 


\section{David Cameron}

Italy has a long tradition of short-lived coalition governments, and the tensions between political parties continued during the pandemic. Indeed, toward the end of January 2021, the government of the popular Prime Minister Giuseppe Conte collapsed after a minor party pulled out of the governing coalition. ${ }^{9}$ Thus, Italy is struggling with political instability while still in the midst of the coronavirus crisis, making it more difficult for timely and effective measures to be implemented. Italy's indifferent performance, then, cannot be explained by any simple measure, but appears to be the product of a mixture of several factors, including bad luck and initial unfamiliarity with the disease, demography, the particular character of the country's health care system, and governance.

The United Kingdom entered the pandemic well positioned to address the challenges of COVID-19 effectively. Britain possessed strong public institutions and had recently elected a strong majority government in Westminster; in the National Health Service (NHS), it had an enviable public health system and came second after the United States in the Global Health Security Index for pandemic preparedness. Yet it sits third from bottom in the table, recording the worst performance among G7 countries, and the third highest number of COVID-19 deaths per million on our OECD list. Why is that?

Britain has devolved significant authority in health matters to the three 'home nations' of Scotland, Wales, and Northern Ireland, but with relatively little autonomous fiscal authority. This meant that the country, faced with the sudden shock of the pandemic, looked naturally to London for leadership. UK performance in the early going, then, was determined by decisions being taken by the UK government, rather than by the Scottish or Welsh governments or the Northern Ireland Assembly, and with relatively little intergovernmental collaboration. The UK government spoke of there being three phases or elements in the policy: containment (handwashing, contact tracing, etc.); delay (flattening the curve so as to not overwhelm the NHS and developing therapies and vaccines); and mitigation (protecting the most vulnerable, but letting the population at large gradually build up herd immunity). This strategy precluded early decisive measures to stop the spread of the virus. The strong public reaction to this approach led to the government rapidly shifting its policy to the suppression of the virus and its transmission with a series of increasingly stringent measures (Calnan 2020). Willing to follow the UK government in the beginning, the devolved governments became increasingly restive as time went on, frustrated by the policy lurches and U-turns. They began to set a more autonomous course, particularly with respect to the regulation of school closures and the easing of pandemic measures. All in all, in the judgment of one observer, while the National Health Service performed very well, "the management of COVID-19 in the UK has been a disaster" (Grace 2021). There is little to suggest that devolution is the culprit responsible for the UK's poor performance; instead, it seems to have been national political leadership and policy making that has most significantly shaped the United Kingdom's low ranking. Indeed, it might be hypothesized that greater devolution might have led to better results. Interestingly, Clive Grace in this volume has made the case that the likely result of Britain's pandemic experience will be to strengthen the push for greater devolution and 'federalisation' of the country, clearly not an outcome that the British government, already struggling with the fissiparous impact of Brexit, would welcome.

Before turning to a discussion of a number of high-performing countries, let me note the experience of the Czech Republic. We have seen that fighting the pandemic is 
closer to a marathon than a 100-yard dash, and that countries which perform well at one point in the process can falter at another. Both the United States and the United Kingdom delivered poor results in the first stage when the issue was controlling the spread of the virus, but have subsequently been global leaders in the administration of COVID-19 vaccines to their citizenry. As of 3 March 2021, Britain and the United States rank second and third among OECD countries for the number of vaccine doses administered per 100 people (OECD, 9 March 2021). The Czech Republic offers another example of variable performance in the long course of coping with the disease. One of the top performers in the first phase of the virus, through a series of mistakes the country now finds itself struggling desperately to gain control of runaway infections in the country. Rastislav Madar, a Czech epidemiologist, identifies three critical decisions in particular that the government got wrong. First the government spurning the advice of its scientific advisors - refused to reinstate the mask-wearing mandate in the summer of 2020, just before the schools reopened. Second, after a surge of infections in October resulting largely from people not wearing masks, the government - not following its own guidelines - decided to reopen shops just before Christmas. And third, it failed to act quickly in response to the emergence of the British variant which became an increasingly important part of the post-Christmas rise in infections in January. The result is that, as of March 2021, the Czech infection rate is close to record levels, just as the number of global infections is starting to drop (Kattasova 2021).

I will turn now to the best performing countries. It is notable that three of the top four performers (New Zealand, Australia, and Japan) are island countries, and the fourth - South Korea - is bordered on three sides by water and in the north by a hard border with the hermit kingdom of North Korea. Does their geographical status make any difference with respect to pandemic control? If one compares these countries with others such as Belgium, Slovenia, the Czech Republic, or Hungary, which are physically embedded in a complex network of abutting states, one would have to acknowledge, I think, that the island or quasi-island status of the countries at the top of the OECD list is at least a facilitating condition in terms of managing a highly infectious virus. Physical contiguity with other nations and a porous land border make national isolation difficult. Imagine Belgium, seeking - through aggressive isolation from its neighbors - to pursue the same policy goal of zero COVID-19 outbreaks as New Zealand. That would seem difficult or impossible to achieve, not only because of Belgium's geographical situation, but because of its status as the de facto capital of the European Union. While I have suggested it is a facilitating condition, it would be a mistake to over-emphasize simple geographical location and specifically insularity. The United Kingdom, after all, is an island country as well, and, as we have seen, it is near the bottom of the list.

Population size and density have also been mentioned as relevant factors. The thought is that a small country will be able to marshal its citizens and manage its policy response more readily than a large country, and that an infectious disease will obviously find it easier to spread in a dense than in a dispersed population. But again, these are very far from being determining factors in successful pandemic control. True enough, New Zealand, the top performer, has a small and relatively dispersed population of just under 5 million with a density of 18 people per square kilometer. Australia, our highest achiever among federations, is a continent-sized island, with vast stretches of unpopulated territory. However, over 80 percent of its citizens 


\section{0}

live in urban settings, some of them fairly large: Sydney and Melbourne each have a population of just under 5 million people. The population density of Australia's two largest cities, though, is low. On the other hand, Japan, a geographically small country, has a large population of 126 million and a national population density ratio of 347 people per square kilometer. Its cities and mega-cities are highly crowded. These demographic realities, however, have not kept it from being the fourth highest OECD performer. While South Korea's population of 52 million is less than half the size of Japan's, its population density is even higher than Japan's at 510 people per square kilometer. Seoul has just under 10 million residents with a population density almost twice that of New York City. Yet South Korea is a top performer.

What then explains high performance? We will start by examining the case of New Zealand, which comes in first in having the lowest number of cases and number of deaths per million population. New Zealand has managed to stop the virus in its tracks; for months at a time, it has been completely virus-free (Baker, Kvalsvig and Verrall 2020). When an outbreak has occurred, they have managed to snuff it out. How so? It was by no means a foregone conclusion at the beginning that the country would bring the virus to its knees. At 35, New Zealand ranked lower than Italy in its preparation for a pandemic according to the Global Health Security Index, and much of the public health advice at the time was directed more at control than total elimination. However, a vigorous debate occurred at the early stages about which strategy to pursue. Prime Minister Jacinda Ardern chose elimination as the Government's policy goal. This set the strategic direction of the country from that point onward: all the decisions that followed were aimed at eliminating the virus, rather than simply trying to control it. The criterion of success was forbidding, but clear, and the strategy equally transparent - early, aggressive implementation of well-understood, evidence-based public-health measures.

The choice of that goal and its highly effective implementation won Ardern and her Labour Party a landslide re-election in the mid-pandemic elections in October 2020. A primary reason the Prime Minister and her government chose elimination was concern over the limited capacity of the country's health care system. To achieve the objective of effectively eliminating the virus, the Prime Minister understood that New Zealand had to act "hard and early" to prevent a loss of control. Once committed, in the words of Richard Parker,

New Zealand's battle to contain the virus followed the classic pattern ordained by the science of virus transmission: stopping the influx of the virus from arriving travelers; procuring personal protective equipment to protect essential workers; testing, contact tracing, and isolating those who test positive; and, most of all, mobilizing the public to lockdown and socially distance so as to slow or break the chain of transmission.

(Parker 2020)

To put it simply, there were three forces at work in New Zealand's successful prosecution of the war against the virus: first, there was excellent leadership, which had been exemplified earlier in Jacinda Ardern's surefooted handling of the Christchurch massacre in March 2019; secondly, there was a responsible and responsive citizenry, with sufficient trust in the country's leadership to accept the "hard and early" measures required; and thirdly, binding the two together, there was the acceptance by both the 
leaders and the lead of the authority of the science of epidemiology - the country followed the science. The full-scale, nationwide lockdown lasted for 26 days, followed by a moderated version of equivalent duration. Since that time, when there have been isolated outbreaks (most recently in Auckland in February 2021), the government has acted swiftly and aggressively to stamp them out.

Let us turn now to the best performing federation, Australia, which comes in third in the rankings after New Zealand and South Korea. Australia, it appears, is a case in which the federal organization of a large country was not only not an impediment to effective action, but overall proved to be beneficial in the prosecution of the attack on the coronavirus. Despite the decentralized constitutional framework of the country (with residual powers, for example, remaining with the states), there has been an inexorable centralization of power in the Commonwealth government, almost from Australia's inception in 1901.

Controlling the three main tax bases and raising 80 percent of all the tax revenue in Australia, the Commonwealth has financial resources far in excess of its program requirements, while the states are dependent on the Commonwealth for almost half their revenue needs.

(Fenna 2021)

One might have expected, therefore, that Australia's success in coping with the pandemic would be a story of the Commonwealth government aggressively swinging into action and pushing the state governments to one side. But this was not the case. Except for the care of the aged, which is a federal responsibility, the states have jurisdiction over most areas that matter during a pandemic: hospitals and most of public health, schools, the regulation of businesses, and the capacity to control their own state borders. While the Commonwealth government declared a 'human biosecurity emergency' under the 2015 Biosecurity Act, giving it sweeping powers (Edgar 2020), each of the States has public health emergency legislation and all but New South Wales declared their own states of emergency (Fenna 2021).

Each order of government implemented measures to control the virus. The Commonwealth Minister for Health, for example, issued several regulations "banning overseas travel, prohibiting cruise ships from entering ports, restricting access to remote, mainly Aboriginal communities and medical isolation zones, and controlling the prices of health-related goods such as disposable face masks, gloves, and hand sanitizer" (Edgar 2020). As for initiatives of the states, there was some variation in policy and timing, arising out of their differing circumstances, but one could argue that that was more of a benefit than a problem, permitting regional governments to respond to local needs and circumstances.

That the many semi-autonomous government actors did not by and large create confusion is owing primarily to the fact that Australia's intergovernmental actors and institutions stepped up to the challenge with what Alan Fenna calls 'loose coordination' (2021). In fact, as he points out, under the auspices of the Council of Australian Governments (COAG), state and federal leaders had begun more than a decade before to put in place legislation and intergovernmental agreements outlining the roles and responsibilities of the two orders of government in the event of a civil or biosecurity emergency of the sort COVID-19 presented. The primary responsibility of the states was recognized, as was the Commonwealth responsibility to offer financial and 


\section{2}

\section{David Cameron}

resource support as necessary. When the pandemic struck, then, there was a framework of understanding to guide the governments in their response. This framework was no doubt one of the factors leading to Australia ranking fourth in the Global Health Security Index. In addition, intergovernmental coordination at the apex was intensified, with COAG, the meeting of first ministers, effectively transformed into what was called the National Cabinet. As Fenna reports, this group began to meet weekly, supported by the Australian Health Protection Principals Committee whose members were the chief medical officers from the Commonwealth and state governments. The National Cabinet seems to have operated in an unusually collegial fashion, exchanging information, seeking consensus, and offering guidelines to all the participants. ${ }^{10}$

One area in which consensus broke down was the question of when to re-open state economies and societies that had been locked down. The Commonwealth government, faced with backstopping the enormous costs of the pandemic, was anxious to re-open as soon as possible, whereas the states, who were managing the impact of the pandemic on the ground, were reluctant to open early. Despite Commonwealth efforts, the states generally held their ground, and the resultant strategy privileged prudence and pandemic control over economic recovery, which contributed to the country's high performance in suppressing the virus.

All in all, the Australian federal system played a critical role in the management of the pandemic and in Australia's success. It allowed for the Commonwealth government to play its part in controlling the external borders of the country and giving financial and other support to the states, as well as leading the ongoing coordination function. The states managed the public health care system on the ground and generally took the lead in lockdowns, as well as in the regulation of schools and businesses. Several states also imposed their own border controls. Shared Commonwealth and state leadership proved to be very popular with the public.

Australian federalism rose to the challenge. Given that the federal government lacks operational boots on the ground, it is difficult to imagine that aggressive, unilateral action by the federal government, of the sort seen in some other formally decentralized systems, would have served the country anywhere near as well. Far from decentralized government being an impediment to high performance, in a large country with diverse conditions and dispersed populations, it appears to have contributed positively to Australia's high achievement.

\subsection{Concluding thoughts on comparative performance}

This brief review indicates that there is no structural impediment to high performance on the part of federal countries. As is the case with their non-federal cousins, federal countries can be found all across the performance scale, with some at or near the very top.

There appear to be some factors common to high-performing countries, whether they are federal or unitary. A decent national public-health and medical-care system is a common denominator. Also associated with high performance is broad public acceptance, shared by the political leadership, of the reality of the virus and the need to accept and act on the scientific understanding of the disease. ${ }^{11}$ Happily, COVID-skeptics in most countries are in relatively short supply. Regulations and guidance, well explained and grounded in public-health science, tend to 
receive broad public acceptance. Public communication - honest, consistent, and evidence-based - builds trust and acceptance in democratic societies which inevitably depend on voluntary acquiescence more than on coercive regulation. But enforcement as a last resort helps to sustain public belief in the shared obligations of all members of society.

Our brief survey suggests that high performance in both federal and non-federal states will be heavily influenced by how well these states are governed. Effective leadership, both political and expert, appears to be critical in shaping a successful national response to the pandemic. ${ }^{12}$ Both Belgium and Italy have been plagued by unstable government, although in the former case the federal system the Belgians have designed for themselves has exacerbated the complications, whereas in the latter governance weakness was only one contributing factor among several. The United States, in the first year of the pandemic, was badly led at the national level and driven throughout by fierce partisanship. The United Kingdom had a strong majority government and a highly regarded National Health Service; however, a willful national political leadership, uninterested in collaborating with its regional partners, led the country astray.

New Zealand and Australia, on the other hand, were very well led, but in very different ways, ways which disclose the difference between what one might call unitary and federal leadership styles. New Zealand's Prime Minister, Jacinda Ardern, did not have to bargain with autonomous regional political actors to set the country on its path. She did begin the pandemic, though, heading a coalition government, which is typical of New Zealand with its mixed member proportional electoral system, and so she had to retain the confidence of her government partners. However, part way through the pandemic, as a result of the election of 17 October 2020, her party won an absolute majority (50.01 percent of the popular vote and 65 of 120 seats), leaving her government no longer reliant on the support of other parties in Parliament. The Prime Minister of New Zealand is unequivocally the leader of the nation and the focal point of the country's politics. In terms of political offices, there is no competition. Her leadership challenge, then, was to retain the confidence of Parliament and the trust of the New Zealand people.

In Australia, however, as in most other federations, the nature of leadership and its location, particularly in the midst of a public-health crisis, are very different. Australia has constitutionally divided authority, with powerful regional politicians invested with substantial authority to act. ${ }^{13}$ Indeed, the states, as we have seen, are primarily responsible for the institutions and the regulations required to combat COVID-19. This sets a very different context for leadership, and in fact changes its quality decisively. To begin with, leadership is to be found in two constitutionally grounded locations, in Canberra and the state capitals. In normal federal politics, the risk of sterile competition is considerable. Intergovernmental relations often invite blame-shifting and buck-passing. The Prime Minister of the country cannot force his will on the state premiers. Particularly in a crisis, there is a premium on a collaborative or collegial style of leadership, which is in fact what Australian Prime Minister Scott Morrison has provided. To a degree, normal conflictual politics were set aside in the light of the pandemic, and the National Cabinet, chaired by Morrison, operated in a collegial fashion. The states retained their autonomy and their broad scope of responsibility to manage the pandemic, while the Commonwealth government addressed the matters for which it was responsible and played a lead coordinating role. This suspension of 


\section{4}

normal politics and heightened collaboration was also apparent in other federations, such as Germany and Canada, although certainly not in all.

Good government and strong political leadership appear to be indispensable ingredients in successful pandemic performance, whatever the form of government. Achieving these qualities in a federation, though, is a more complex undertaking than it is in a unitary state.

The principle of distributed authority is expressed throughout a federation - in its constitutional and legislative structure, in its public administration, and in its citizenry and the electoral systems by which the people's representatives are chosen. A kind of federal diplomacy largely unknown in unitary systems is part of good federal practice, both administratively and politically. And citizens are members of both a provincial and a national community. They have loyalties and democratic representatives at both levels whose respective responsibilities are often not clear or not well understood. It is a world in which good government in a public-health crisis is inevitably a collegial endeavor among autonomous actors.

All that being said, I would conclude that the constitutional form of a democratic country, be it federal or non-federal, does not determine pandemic-management outcomes, but it establishes the frame within which those outcomes are determined. The pursuit of high achievement in federal and non-federal states requires different leadership styles, accountability structures, public administration practices, and citizen expectations. New Zealand performed outstandingly well, partly because it clearly set a demanding but achievable goal for itself - total victory over the virus - and pursued it zealously within a clearly defined, coherent authority structure. Australia, for its part, did a remarkable job in severely constraining the virus in a more complex constitutional and political environment in which success was determined by the collaborative performance of multiple autonomous actors. While factors such as geography and history played a noticeable role, perhaps what mattered most in confronting the coronavirus were two considerations: the quality of leadership at all levels and in all professional spheres, which established a bond of trust between the leaders and the led; and good governance, which permitted effective organization, timely interventions, and the application of the required resources of the state to combating the disease.

Please note: This chapter was previously published by the Forum of Federations as Occasional Paper \#50: http://www.forumfed.org/wp-content/uploads/2021/04/ OPS50_Relative_Performance_During_the_Pandemic1.pdf

\section{Notes}

1 We can see already (March 5, 2021) that poor performance in the first phase is no predictor of performance in the second. The United Kingdom and the United States both did poorly in the first phase but are among the global leaders in administering the vaccine in the second phase.

2 OECD members Colombia, Hungary, and Mexico are listed as 'partly free' in the 2020 Freedom House index. The other 33 members are rated as 'free'.

3 They are all, for example, in the upper half of the nominal GDP per capita range.

4 We have excluded two OECD countries with populations less than a million from the list: Iceland and Luxembourg.

5 Despite the fact that the United Kingdom appears in this volume, albeit as a system of devolved government with 'federalised' arrangements, we will treat it in this chapter as a non-federal country, which indeed it is. 
6 It is worth noting, though, that on the Global Health Security Index Belgium came in seventh place among the nine OECD federations in terms of pandemic preparedness.

7 But see Gordon, Huberfield and Jones (2020). They argue that: 'In this pandemic, US public health federalism assures that the coronavirus response depends on zip code. A global pandemic has no respect for geographic boundaries, laying bare the weaknesses of federalism in the face of a crisis." As Kumanan et al. (2008) point out, the United States, along with Canada and Australia, do confront "the challenge that authority over several of the core capacity requirements (is) primarily located at the state or province level” (p. 217).

8 The information in this paragraph is drawn chiefly from Boccia, Ricciardi and Ioannidis (2020, pp. 927-928).

9 A non-partisan technocrat, Mario Draghi, replaced the outgoing Prime Minister, Giuseppe Conte, in February 2021.

10 As with many other countries, long-term care of the elderly was an area where coordination appears to have faltered with unfortunate results. In Australia's case, the nexus between aged care, which fell under Commonwealth responsibility, and hospitals, which were the domain of the states, was at the center of the problem.

11 This might seem so obvious as to not need mentioning, but unfortunately, we have seen several cases of denialism, some in developed countries (the United States) and some in developing countries (Brazil and Tanzania). South Africa experienced an earlier case of medical denialism when former South African President Thabo Mbeki resisted the scientific evidence and medical treatment of HIV/AIDS.

12 Combating the spread of a highly infectious virus poses a distinctive challenge for political and expert leadership, because, unlike most policy fields, pandemic management requires an active commitment on the part of citizens to alter their conduct and daily practices quarantining, wearing masks, social distancing, and the like.

13 In some federations, this regional authority has been deployed with some success to create 'bubbles' shielding sub-national units from the spread of the virus affecting other parts of the country. For several months, the Atlantic provinces of Canada established an 'Atlantic Bubble' with border controls and quarantine provisions. During this period, life went on in these provinces in a manner rather similar to life in New Zealand once that country had eliminated the virus.

\section{Bibliography}

Baker, M.G., Kvalsvig, A. and Verrall, A.J., 2020. New Zealand's COVID-19 Elimination Strategy. The Medical Journal of Australia, 213 (5), 198-200. Available from: https://doi. org/10.5694/mja2.50735 [Accessed 7 April 2021].

Boccia, S., Ricciardi, W. and Ioannidis, J.P.A., 2020. What Other Countries Can Learn from Italy During the COVID-19 Pandemic. JAMA Internal Medicine, 180 (7), 927-928. Available from: https://jamanetwork.com/journals/jamainternalmedicine/fullarticle/2764369 [Accessed 7 April 2021].

Bursens, P., Popelier, P. and Meier, P., 2021. Belgium's Response to COVID-19: How to Manage a Pandemic in a Competitive Federal System? In: Chattopadhyay, R., Knüpling, F., Chebenova, D., Gonzalez, P. and Whittington, L., eds. Federalism and the Response to COVID-19: A Comparative Analysis, Chapter 5. Canada: Routledge.

Calnan, M., 2020. England's Response to the Coronavirus Pandemic - Now Updated [online]. Cambridge Core Blog, 6 August 2020. Available from: https://www.cambridge.org/core/ blog/2020/04/06/englands-response-to-the-coronavirus-pandemic/ [Accessed 7 April 2021].

Camacho, A.E. and Glickman, R.L., 2020. The Trump Administration's Pandemic Response is Structured to Fail. The Regulatory Review, University of Pennsylvania Law School, 19 May 2020. Available from: https://www.theregreview.org/2020/05/19/camacho-glicksmantrump-administration-pandemic-response-structured-fail/ [Accessed 7 April 2021].

Edgar, A., 2020. Disrupting Administrative Law in a Public Health Crisis [online]. The Regulatory Review, 24 April 2020. Available from: https://www.theregreview.org/2020/04/24/ edgar-disrupting-administrative-law-public-health-crisis/ [Accessed 6 May 2021]. 


\section{David Cameron}

Fenna, A., 2021. Australian Federalism and the COVID-19 Crisis. In: Chattopadhyay, R., Knüpling, F., Chebenova, D., Gonzalez, P. and Whittington, L., eds. Federalism and the Response to COVID-19: A Comparative Analysis Chapter 3. Canada: Routledge.

Gordon, S.H., Huberfield, N. and Jones, D.K., 2020. What Federalism Means for the US Response to Coronavirus Disease 2019. Available from: https://jamanetwork.com/channels/ health-forum/fullarticle/2766033 [Accessed 7 April 2021].

Grace, C., 2021. Perfect Storm: The Pandemic, Brexit, and Devolved Government in the UK. In: Chattopadhyay, R., Knüpling, F., Chebenova, D., Gonzalez, P. and Whittington, L., eds. Federalism and the Response to COVID-19: A Comparative Analysis, Chapter 23. Canada: Routledge.

Hasell, J., Mathieu, E., Beltekian, D., et al. 2020. A Cross-Country Database of COVID-19 Testing. Scientific Data, 7, 345. Available from: https://doi.org/10.1038/s41597-02000688-8 [Accessed 7 April 2021].

Johns Hopkins University Coronavirus Resource Center, 2021. COVID-19 Dashboard by the Center for Systems Science and Engineering (CSSE) at Hopkins University [dataset]. 24 March. Available from: https://coronavirus.jhu.edu/map.html [Accessed 6 April 2021].

Kattasova, I., 2021. How the Czech Republic Slipped into a Covid Disaster, One Misstep at a Time [online]. CNN, 1 March 2021. Available from: https://www.cnn.com/2021/02/28/ europe/czech-republic-coronavirus-disaster-intl/index.html [Accessed 6 May 2021].

Kincaid, J. and Leckrone, W.J., 2021. COVID-19 and American Federalism: First-Wave Responses. In: Chattopadhyay, R., Knüpling, F., Chebenova, D., Gonzalez, P. and Whittington, L., eds. Federalism and the Response to COVID-19: A Comparative Analysis, Chapter 24. Canada: Routledge.

Kumanan, W., McDougal, C., Fidler, D.P. and Lazar, H., 2008. Strategies for Implementing the New International Health Regulations in Federal Countries. Bulletin of the World Health Organization, 86 (3), 4.

Mammone, A., 2021. "Italy's Political Crisis is an Opportunity for the Far Right," Al Jazeera, 9 February 2021. Available from: https://www.aljazeera.com/opinions/2021/2/9/italyspolitical-crisis-is-an-opportunity-for-the-far-right [Accessed 7 April 2021].

Nicola, F.G., 2020. Exporting the Italian Model to Fight COVID-19 [online]. The Regulatory Review, University of Pennsylvania Law School, 23 April 2020. Available from: https://www.theregreview.org/2020/04/23/nicola-exporting-italian-model-fight-covid-19/ [Accessed 7 April 2021].

OECD, 9 March 2021. Daily Rollout of COVID-19 Vaccinations [online]. Available from: https://www.oecd.org/coronavirus/en/data-insights/ieo-2021-03-more-jabs-more-jobs [Accessed on 7 June 2021].

Palermo, F., 2021. The Impact of the Pandemic on the Italian Regional System: Centralizing or Decentralizing Effects? In: Chattopadhyay, R., Knüpling, F., Chebenova, D., Gonzalez, P. and Whittington, L., eds. Federalism and the Response to COVID-19: A Comparative Analysis, Chapter 12. Canada: Routledge.

Parker, R.W., 2020. Lessons from New Zealand's COVID-19 Success [online]. The Regulatory Review, 9 June 2020. Available from: https://www.theregreview.org/2020/06/09/parkerlessons-new-zealand-covid-19-success/ [Accessed 7 April 2021]. 